\title{
Implementation of Alternative Delivery Mode Learning Resources Amidst COVID-19 Pandemic: Basis for Intervention Program
}

\author{
John Mark R. Asio ${ }^{1}$, Edward C. Jimenez ${ }^{2}$ \\ ${ }^{1}$ Research Development and Community Extension Services, Gordon College. \\ Olongapo City, Philippines. \\ ${ }^{2}$ Department of Education, Schools Division of the City of Meycauayan. Bulacan, \\ Philippines.
}

Article History
Received:
19.10 .2021
Revised:
23.11 .2021
Accepted:
17.12.2021
*Corresponding Author:
John Mark R. Asio
Email:
asio.johnmark@gmail.com

This is an open access article, licensed under: $\mathrm{CC}-\mathrm{BY}-\mathrm{SA}$

\begin{abstract}
This study aimed to assess the implementation of the Alternative Delivery Mode (ADM) Learning Resources as a basis for an intervention program amidst the COVID-19 pandemic. The study employed a descriptive survey research design. Using a universal sampling technique, a total of 30 Learning Resource Coordinators in a selected school division in Central Luzon, Philippines participated in the survey and data gathering. The researchers also used an adapted research instrument to gather essential information for the study. With the help Microsoft Excel, the researchers tabulated and organized the data. Afterwards, the gathered data underwent descriptive statistical analysis using frequency and percentage. The study found that the ADM Learning Resources developed by teachers exceeded DepEd's total number of Most Essential Learning Competencies (MELCs). For the total number of learners who preferred modular printed learning modality, it reached $67.89 \%$. There were $100 \%$ ADM Learning Resources provided to learners in all grade levels for the status of printed learning resources. Based on the earlier results, the researcher provided some essential recommendations, particularly an intervention program for this study.
\end{abstract}

Keywords: Alternative Delivery Mode, COVID-19 Pandemic, Intervention Program, Learning Resources, Most Essential Learning Competencies. 


\section{Introduction}

Assessment is a term used by educators to evaluate, measure, and document students' academic readiness, learning progress, skill acquisition, or educational needs. It uses a variety of methods and tools to provide a representative overview of a few major forms of educational appraisal. The notion of "resources" is often framed in an economic sense like money, time, equipment, and the like. Resources are the potential to participate in socio-cultural action through a series of reflections [1]:

1. demonstrate that curriculum can be productively thought as a route marker for development of resources

2. show that lecturers bring tacit resources for trust, care, creativity, and credibility to the teaching and learning space, and

3. reflect on how students' prior learning experiences can be harnessed as a resource teaching and learning

According to a research article, it revealed that Online Information Resources (OIR) contributed significantly to both Open Distance and Lifelong learning [2. The study also highlights the increased desire for continued learning and the suitability of the OIR in enhancing learning and ensuring inclusive and equitable quality education.

The same study conducted by an author about learning progressions as tools for assessment and learning points out the importance of learning progression as an essential resource for teacher learning [3]. The proponent stressed that learning progressions require interactive development cycles to build horizontal coherence in curriculum, instruction, and assessment. These help teachers engage their students in more affluent and equitable learning experiences accompanying professional development and institutional support.

Meanwhile, assessment and learning measurement are receiving increasing emphasis in higher education, as posited by Lovett \& Curtis [4] in their study entitled "Assessment under Resources Constraints". The study demonstrated a simple, inexpensive method of measuring freshman to senior "gains" or learning using a cross-sectional methodology. It also revealed that seniors' average score on all parts was higher than that of first-year students.

An earlier work from a group of investigators showed that the long-standing purpose of assessment is to help faculty improve student learning [5]. Learning improvement evidence in its simplest form requires practitioners to assess, intervene, and re-assess a student learning outcome. They suggested that coordinating such a diverse group toward a common improvement goal requires a new Learning Improvement Facilitator (LIF) or skillset. This skillset possesses excellent facilitation skills and is attuned to group dynamics, organizational nuances, and interpersonal communication.

According to the group of Nilsen [6] in their study on producing digital learning resources (DLR) for teacher training, digital learning resources are crucial to implementing this teaching adequately. It found out that several aspects of the design process can enhance teacher trainers and the development of digital learning content in higher education.

Furthermore, in assessing the computer programs' appropriateness and quality, a group found that the computer program is feasible for high school physics learning and learning media experts [7]. Thus, high school physics teachers revealed the quality of computer programs excellent. Normalize gains from the pre-test and post-test are found as 0.68 and 0.55 , respectively. This implies that there is a medium improvement of students' learning achievement after using the computer program as a learning resource.

On the other hand, a study conducted by Jimenez [8] on the impact of contextualized e-learning resources as tools for a more robust academic platform showed no significant difference between the means of pre-test scores of the two groups. This result means that the use of contextualized e-learning resources in teaching significantly increases learners' academic performance. He also mentioned that the electronic tools provided by the teachers created a sound learning environment to master the least learned competencies.

Another study presented by the team of Babcock [9] entitled "Mind the Gaps: An Online Learning Center's Needs Assessment" pointed out that a needs assessment was conducted to understand administrator, faculty, and student perceptions of the center's services and resources to uncover gaps between the current state and intended outcomes like personalized support, clarity of services, and shared accountability for student success. They also posited a need to empower students.

In the realm of the study conducted by Strawser and Neuberger [10], the paper proposes a framework that addresses the thorny issue via writing, immersive experiences, speaking, honest 
communication, and research (WISER). These five pillars of the communication discipline faculty can use to ensure their assessment efforts to achieve the goal of documenting and improving student learning.

Students should be appropriately assessed to acquire a great deal of college-level knowledge and skills through their day-to-day lives outside of academia: from work experience, on-the-job training, formal corporate training, military training, volunteering work, self-study, and countless other extrainstitutional learning opportunities available [11]. The call for recognizing and awarding credit for college-level learning acquired outside of the classroom is what we call Prior Learning Assessment (PLA). Through this, students have several ways to demonstrate their learning and earn credit in college: standardized examination, faculty-developed challenge exam, portfolio-based, and other individualized assessments are some of these methods.

According to Slater and Davies [12], creating engaging online resources is an essential part of the rapidly changing discipline of e-tutoring. Their study revealed that students favored online lectures, course notes, primary literature, and tutors' resource opinion. They perceived these as accessible, easy to engage with, assignment-related, and provided something akin to a "university campus experience".

This study gained related insights and perspective on how the division would have to manage the development, preparation, and evaluation of different learning resources efficiently and effectively. The literature presented gave a credible understanding of the assessment of learning resources to provide comprehensive and formative program processes that would ensure the quality of the learning resources to be distributed to the schools. An important key factor in assuring the outcome produced by the output guarantees a holistic feedback mechanism to continuously provide an assessment of learning, assessment of learning resources, and assessment of learning outcomes. This finding may result in a better intervention program or framework that channels the critical role of the quality assurance process, ADM management system, and utilization of ADM learning resources in the organization. These solutions lead to different learning opportunities and a sound environment amongst school heads, teachers, learners, and stakeholders.

\section{Methodology}

\subsection{Research Design}

This research paper involves quantitative research with a descriptive survey design as a basic premise. Since the study's primary concern of the current study was to assess the alternative delivery mode (ADM) learning resources as a basis for an intervention program amidst the COVID-19 pandemic, the research design used was appropriate and fitted the job.

\subsection{Respondents}

The study's respondents include 30 learning resource (LR) coordinators of the elementary and secondary schools in the Schools Divisions of the City of Meycauayan for the school year 2020-2021. To determine the appropriate number of respondents for the study, the researchers used a universal sampling technique. They considered all of the learning resource coordinators in the school division for equal opportunity to be part of the survey. Table 1 below shows the distribution of the respondents.

Table 1. Frequency and Percentage Distribution of Respondents

\begin{tabular}{ccc}
\hline Cluster of Schools & Frequency & Percentage \\
\hline A & 8 & 27 \\
B & 9 & 30 \\
C & 8 & 27 \\
D & 5 & 16 \\
\hline TOTAL & 30 & 100 \\
\hline
\end{tabular}

\subsection{Instrument of the Study}

The researchers used the Department of Education-Learner's Resources Situation Report by the Bureau of Learning Resources. This form is a per-grade level tabular report template. It assesses the actual quantity of the Alternative Delivery Mode (ADM) materials with losses and damages, and 
usable numbers with the corresponding number of enrolments and the number of shortage or deficiency and excess.

\subsection{Data Collection and Analysis}

Before conducting the study, the researcher sought permission from the Schools Division Superintendent of the City of Meycauayan. Upon receiving the approved permit, the researcher coordinated with the school heads (SHs) through phone or the Messenger application program to schedule quantitative data collection. Due to the pandemic, the researcher administered the questionnaire to the target respondents employing social media platforms such as Facebook or email and through phone calls.

The data was collected through Google Sheets. The confidentiality of the result assured its security with anonymity. The data was stored in the Learning Resource Management and Development Section (LRMDS) Office for filing and official business reference. At the same time, the transfer of it is prohibited unless for legal purposes. The researchers strictly followed the procedure in the data collection to secure the identity of the persons involved and the secrecy of information.

In the data gathering, the questionnaire utilized was the DepEd-BLR Learners' Resources Situation Report in identifying the definite number of LRs distributed to schools under the "new normal" education based on MELCs.

The result of the data collection was tabulated and treated using statistical software. This study used descriptive statistics like frequency count and percentages on the responses of the respondents.

\section{Results}

This study aimed to assess the implementation of Alternative Delivery Mode (ADM) to the different public elementary and high schools in a school division in Meycauayan City, Bulacan, Philippines. The following tables below summarize the results of the study.

Table 2. Status of Learning Resources as to Number of Most Essential Learning Competencies (MELCs)

\begin{tabular}{lccccc}
\hline \multirow{2}{*}{ Subject } & \multicolumn{4}{c}{ Quarter } & \multirow{2}{*}{ TOTAL } \\
\cline { 2 - 4 } & $\mathbf{1}^{\text {st }}$ & $\mathbf{2}^{\text {nd }}$ & $\mathbf{3}^{\text {rd }}$ & $\mathbf{4}^{\text {th }}$ & \\
\hline Numeracy \& Literacy & 16 & 18 & 11 & 22 & 57 \\
MTB & 72 & 20 & 30 & 13 & 135 \\
Filipino & 152 & 178 & 166 & 167 & 663 \\
English & 53 & 47 & 69 & 53 & 222 \\
Science & 35 & 60 & 41 & 50 & 186 \\
Math & 149 & 142 & 136 & 114 & 541 \\
Araling Panlipunan & 68 & 59 & 60 & 64 & 251 \\
EPP/TLE & 300 & 149 & 164 & 46 & 659 \\
MAPEH & 248 & 253 & 258 & 239 & 998 \\
EsP & 91 & 97 & 83 & 47 & 318 \\
\hline TOTAL & $\mathbf{1 , 1 8 4}$ & $\mathbf{1 , 0 2 3}$ & $\mathbf{1 , 0 1 8}$ & $\mathbf{8 1 5}$ & $\mathbf{4 , 0 4 0}$ \\
\hline
\end{tabular}

Table 2 shows the list of the New Normal Most Essential Learning Competencies (MELCs) provided by the DepEd for the SY 2020-2021. As gleaned from the table, subject MAPEH has the most MELCs with 998 MELCs due to its four (4) components, namely: Music, Arts, PE, and Health. Filipino subject followed it with 663 MELCs, EPP/TLE with 659 MELCs across Home Economics, Industrial Arts, Agri-Fishery Arts, and ICT, Mathematics with 541, EsP with 318, Araling Panlipunan with 251, English with 222, MTB with 135, and Numeracy \& Literacy with 57 MELCs, respectively. The overall number of MELCs given by DepEd is 4,040. Based on the following accounts, the Department of Education showed the standard number of MELCs for learners to acquire for the whole school year and for the public schools to adapt and follow. 
Table 3. Number of Available Alternative Delivery Mode (ADM) Learning Resources

\begin{tabular}{lccccc}
\hline \multirow{2}{*}{ Subject } & \multicolumn{4}{c}{ Quarter } & \multirow{2}{*}{ TOTAL } \\
\cline { 2 - 4 } & $\mathbf{1}^{\text {st }}$ & $\mathbf{2}^{\text {nd }}$ & $\mathbf{3}^{\text {rd }}$ & $\mathbf{4}^{\text {th }}$ & \\
\hline Numeracy \& Literacy & 24 & 10 & 10 & 10 & $\mathbf{5 4}$ \\
MTB & 38 & 29 & 20 & 23 & $\mathbf{1 1 0}$ \\
Filipino & 85 & 131 & 76 & 80 & $\mathbf{3 7 2}$ \\
English & 90 & 80 & 87 & 94 & $\mathbf{3 5 1}$ \\
Science & 111 & 143 & 142 & 68 & $\mathbf{4 6 4}$ \\
Math & 165 & 127 & 103 & 89 & $\mathbf{4 8 4}$ \\
Araling Panlipunan & 80 & 136 & 79 & 79 & $\mathbf{3 7 4}$ \\
EPP/TLE & 176 & 44 & 128 & 118 & $\mathbf{4 6 6}$ \\
MAPEH & 347 & 288 & 265 & 415 & $\mathbf{1 , 3 1 5}$ \\
EsP & 76 & 51 & 62 & 33 & $\mathbf{2 2 2}$ \\
\hline TOTAL & $\mathbf{1 , 1 9 2}$ & $\mathbf{1 , 0 3 9}$ & $\mathbf{9 7 2}$ & $\mathbf{1 , 0 0 9}$ & $\mathbf{4 , 2 1 2}$ \\
\hline
\end{tabular}

Table 3 shows the total number of Available Alternative Delivery Mode (ADM) Learning Resources or Locally Produced Materials developed by teachers at the Schools Division of the City of Meycauayan for the School Year 2020-2021. The table illustrates that the overall total ADM Learning Resources with 4,212. Among the ten subject areas, MAPEH got the most LRs with 1,315 materials. At the same time, the least number was Numeracy \& Literacy for Kindergarten learners with 54 Learning Resources.

Table 4. Number of Enrolled Learners Printed Learning Modality

\begin{tabular}{lccc}
\hline \multicolumn{1}{c}{ School } & $\begin{array}{c}\text { No. of Enrolled } \\
\text { Learners With Printed } \\
\text { Learning Modality }\end{array}$ & $\begin{array}{c}\text { Number of } \\
\text { Enrollees }\end{array}$ & $\begin{array}{c}\text { \% of Learners with } \\
\text { Printed Learning } \\
\text { Modality }\end{array}$ \\
\hline 1. Bagbaguin ES & 1,671 & 1,667 & $100 \%$ \\
2. Bahay Pare ES & 413 & 669 & $61.73 \%$ \\
3. Bancal IS & 475 & 644 & $73.76 \%$ \\
4. Bancal Extension ES & 206 & 206 & $100 \%$ \\
5. Banga ES & 451 & 524 & $86.07 \%$ \\
6. Bayugo ES & 1,176 & 1,206 & $97.51 \%$ \\
7. Caingin Bayanihan ES & 391 & 420 & $93.10 \%$ \\
8. Calvario ES & 1,151 & 1,187 & $96.97 \%$ \\
9. Camalig ES & 690 & 981 & $70.34 \%$ \\
10. Iba ES & 780 & 1,317 & $59.23 \%$ \\
11. Langka IS & 554 & 554 & $100 \%$ \\
12. Lawa ES & 1,108 & 1,351 & $82.01 \%$ \\
13. Libtong ES & 885 & 1,262 & $70.13 \%$ \\
14. Liputan ES & 191 & 191 & $100 \%$ \\
15. Longos ES & 360 & 360 & $100 \%$ \\
16. Malhacan IS & 646 & 1,429 & $45.21 \%$ \\
17. Meycauayan West Central IS & 1,544 & 2309 & $66.87 \%$ \\
18. Pajo ES & 693 & 929 & $74.60 \%$ \\
19. Pandayan ES & 652 & 972 & $67.08 \%$ \\
20. Pantoc ES & 861 & 1,008 & $85.42 \%$ \\
21. Perez ES & 1,501 & 2,194 & $68.41 \%$ \\
22. Saluysoy IS & 990 & 1,287 & $76.92 \%$ \\
\hline
\end{tabular}

\section{TOTAL}




\begin{tabular}{|c|c|c|c|}
\hline School & $\begin{array}{c}\text { No. of Enrolled } \\
\text { Learners With Printed } \\
\text { Learning Modality } \\
\end{array}$ & $\begin{array}{l}\text { Number of } \\
\text { Enrollees }\end{array}$ & $\begin{array}{c}\text { \% of Learners with } \\
\text { Printed Learning } \\
\text { Modality }\end{array}$ \\
\hline 23. Bagbaguin ES & 1,671 & 1,667 & $100 \%$ \\
\hline 24. Bahay Pare ES & 413 & 669 & $61.73 \%$ \\
\hline 25. Bancal IS & 475 & 644 & $73.76 \%$ \\
\hline 26. Bancal Extension ES & 206 & 206 & $100 \%$ \\
\hline 27. Banga ES & 451 & 524 & $86.07 \%$ \\
\hline 28. Bayugo ES & 1,176 & 1,206 & $97.51 \%$ \\
\hline 29. Caingin Bayanihan ES & 391 & 420 & $93.10 \%$ \\
\hline 30. Calvario ES & 1,151 & 1,187 & $96.97 \%$ \\
\hline 31. Camalig ES & 690 & 981 & $70.34 \%$ \\
\hline 32. Iba ES & 780 & 1,317 & $59.23 \%$ \\
\hline 33. Langka IS & 554 & 554 & $100 \%$ \\
\hline 34. Lawa ES & 1,108 & 1,351 & $82.01 \%$ \\
\hline 35. Libtong ES & 885 & 1,262 & $70.13 \%$ \\
\hline 36. Liputan ES & 191 & 191 & $100 \%$ \\
\hline 37. Longos ES & 360 & 360 & $100 \%$ \\
\hline 38. Malhacan IS & 646 & 1,429 & $45.21 \%$ \\
\hline 39. Meycauayan West Central IS & 1,544 & 2309 & $66.87 \%$ \\
\hline 40. Pajo ES & 693 & 929 & $74.60 \%$ \\
\hline 41. Pandayan ES & 652 & 972 & $67.08 \%$ \\
\hline 42. Pantoc ES & 861 & 1,008 & $85.42 \%$ \\
\hline 43. Perez ES & 1,501 & 2,194 & $68.41 \%$ \\
\hline 44. Saluysoy IS & 990 & 1,287 & $76.92 \%$ \\
\hline 45. Tugatog ES & 373 & 373 & $100 \%$ \\
\hline 46. Ubihan ES & 0 & 249 & $0 \%$ \\
\hline 47. Zamora ES & 204 & 250 & $81.60 \%$ \\
\hline 48. Bancal HS - JHS & 1,085 & 1169 & $92.81 \%$ \\
\hline 49. Langka HS - JHS & 0 & 240 & $0 \%$ \\
\hline 50. Malhacan IS - JHS & 550 & 885 & $62.15 \%$ \\
\hline 51. MNHS & 719 & 3,880 & $18.53 \%$ \\
\hline 52. MNHS-Annex & 517 & 835 & $61.92 \%$ \\
\hline 53. MWCIS - JHS & 1,606 & 1,677 & $95.77 \%$ \\
\hline 54. Saluysoy IS - JHS & 587 & 695 & $84.46 \%$ \\
\hline 55. Ubihan HS & 93 & 133 & $69.92 \%$ \\
\hline 56. ASHSCOM & 90 & 203 & $44.33 \%$ \\
\hline 57. CVMSHS & 0 & 143 & $0 \%$ \\
\hline 58. MNHS-SHS & 34 & 837 & $4.06 \%$ \\
\hline 59. Ubihan SHS & 22 & 41 & $53.66 \%$ \\
\hline TOTAL & 23,269 & 34,277 & $67.89 \%$ \\
\hline
\end{tabular}

Table 4 represents the total number of learners who preferred to have the printed learning modality for the SY 2020-2021. For the elementary, Bagbaguin ES, Bancal Extension ES, Langka IS, Liputan ES, Longos ES, and Tugatog ES revealed $100 \%$ of learners choosing printed learning modality. In comparison, Ubihan ES got $0 \%$ of learners. This decision is because their learners chose other learning modalities.

MWCIS got the highest number of learners who chose printed learning modality for junior high schools with $95.77 \%$ or 1,606 over the total learners of 1,677 . In comparison, the lowest number of learners was got by Langka IS with $0 \%$. This result means that the learners chose other learning modalities instead of the printed one.

Lastly, Ubihan SHS got the highest number of learners for the senior high schools with 22 over 41 or $53.66 \%$ learners. In contrast, CVMSHS got $0 \%$ of learners. It implies that the school utilized other learning modalities. 


\section{Discussion}

Accounting for the study's primary objective of assessing the implementation of Alternative Delivery Mode (ADM) learning resources, the researchers found some interesting results. These results may contribute to a policy or intervention program.

In summary, the study showed strong evidence of compliance in the Alternative Delivery Mode (ADM) implementation of all the participating schools in the division. This result is reflected based on the high overall percentage of distribution of printed learning modality. Although some schools still preferred online learning rather than printed modules, the study showed that there were still more students that preferred such a mode of learning.

A local study by Callo and Yazon [13] revealed that familiarity, capability, preparation, devices, connectivity self-efficacy, and experience with technology determines the readiness of both students and faculty. The findings of another study showed a strong indication of teaching presence based on the roles and actions of K-12 teachers and students, leading to building a learning community [14]. From a different approach, a study evaluated the relationship between alternative delivery mode programs and the students' performance and found a significant relationship between the two variables [15]. A study by Diamante and Banca [16] revealed that there was a significant relationship between the learning styles and skills in general Mathematics with the use of alternative delivery mode to students' performance. A study with thematic analysis also posited that the most common research in the alternative learning system area was on the impact of the system on learners, instructional resources development, and concerns to teaching and learning [17]. In a related study, many teachers experienced difficulties coping with work demands due to alternative delivery mode (ADM). However, they chose to rise above the circumstances and find beauty and inspiration to maintain their sanity through strain and exertion [18]. In addition, a study by Calimlim et al. [19] revealed that teachers in a particular subject were very much ready in the alternative learning delivery modalities. Furthermore, teachers believe that they were ready, possessed necessary skills and have desirable attitude towards alternative mode of teaching [20].

As seen from the different studies in the country, the implementation of Alternative Delivery Mode (ADM) has a positive impact on students' learning process regardless of the subject taught and the different circumstances that teachers experienced. This reflects effectiveness on implementing the $\mathrm{ADM}$ in the schools' division and the efforts and struggles of the teachers and learning resource coordinators.

\section{Conclusion}

From the study results, the researchers concluded that there was a total of 4,040 number of Most Essential Learning Competencies (MELCs) from the ten (10) subject areas being taught in the schools as mandated by the Department of Education. In terms of the Alternative Delivery Mode (ADM), a total of 4,212 learning resources were provided with MAPEH (Music, Arts, Physical Education, and Health) with the most number. For the actual number of learners who preferred printed learning modules for School Year 2020-2021, 67.89\% of 34,277 enrolled learners opted for printed learning modality.

Based on the previous results and conclusion, the researchers, as a result of this, offered the following:

(1) LR Coordinators should continue to mobilize the utilization of ADM Learning Resources or the Locally Developed Materials that are contextualized for the diverse learners of the SDO Meycauayan City.

(2) School Heads should maintain a high level of safety and sound protocols to the teachers as to protect each from the spread of the virus, especially on, during, and after the preparation, distribution, and retrieval of ADM Learning Resources.

(3) LR Manager should maintain the high standard in quality assurance process to prevent bias and content-error that would mislead the learners and parents/guardians.

(4) LR Manager and the Pool of Learning Resource Evaluators (LREs) should follow the empirical program-process of the quality assurance process for the continuous development of quality, accessibility, contextualized. Timely learning resources based on the latest trends in education, particularly this time of "new normal", is encouraged. Lastly, an intervention program to enhance and strengthen the Alternative Delivery Mode (ADM) delivery to all public and private institutions from the kindergarten level to the senior high school. 


\section{References}

[1] Z. Simpson, H. Inglis, and C. Sandrock, "Reframing Resources in Engineering Teaching and learning," Africa Education Review, vol. 17, no. 3, pp. 175-188, 2020.

[2] A. J. Oladipo and O. C. Okiki, "Assessment of the Contribution of Online Information Resources in open Distance Learning Mode to the Development of Lifelong Learning in Southwest, Nigeria," Journal of Library \& Information Services in Distance Learning, vol. 14, no. 1, pp. 79-93, 2020.

[3] L. A. Shepard, "Learning Progressions as Tools for Assessment and Learning," Applied Measurement in Education, vol. 31, no. 2, pp. 165-174, 2017.

[4] S. Lovett and M. G. Curtis, "Assessment under resource constraints," Current Issues in Education, vol. 18, no. 1, Mar 2015.

[5] K. L. Smith, M. R. Good, and N. Jankowski, "Considerations and Resources for the Learning Improvement Facilitator," Research \& Practice In Assessment, vol. 13, pp. 20-26, 2018.

[6] A. G. Nilsen, A. G. Almås, and H. Gram, "Producing Digital Learning Resources (DLR) for Teacher Training," Designs for Learning, vol. 12, no. 1, pp. 71-80, 2020.

[7] E. Pratidhina, P. Pujianto, and Y. Sumardi, "Developing Computer Program as a Learning Resource on Gas Law Topics for High School Students," International Journal of Instruction, vol. 12, no. 2, pp. 133-146, 2019.

[8] E. C. Jimenez, "Contextualized E-learning resource: A Tool for Stronger Academic Platform," International Journal of Case Studies in Business, IT, and Education (IJCSBE), vol. 4, no. 2, pp. 110-116, Sep 2020.

[9] A. Babcock, T. Lehan, and H. Hussey, "Mind the Gaps: an Online Learning Center's Needs Assessment," Journal of TLAR, vol. 24, no. 1, 2019.

[10] M. Strawser and L. Neuberger, "Wiser Assessment: A Communication Program Assessment Framework," Journal of Communication Pedagogy, vol. 3, pp. 134-144, 2020.

[11] A. D. Goldstein, "HBCUs and prior Learning Assessments." [Online]. Available: https://wiche.testing.brossgroup.com/wp-content/uploads/2020/10/tmcf-brief-100620.pdf. [Accessed: October 2021].

[12] D. R. Slater and R. Davies, "Student Preferences for Learning Resources on a Land-Based Postgraduate Online Degree Programme," Online Learning, vol. 24, no. 1, 2020.

[13] E. C. Callo and A. D. Yazon, "Exploring the Factors Influencing the Readiness of Faculty and Students on Online Teaching and Learning as an Alternative Delivery Mode for the New Normal," Universal Journal of Educational Research, vol. 8, no. 8, pp. 3509-3518, 2020.

[14] J. A. R. Villanueva, "Teaching Presence in K-12 Blended Learning Classes under the Alternative Delivery Mode," International Journal on Open and Distance e-Learning, vol. 7, no. 1, pp. 31-52, June 2021.

[15] N. E. Lucero, "Alternative Delivery Mode (ADM) Program Delivery and Performance of Students," European Journal of Open Education and E-learning Studies, vol. 5, no. 2, 2020.

[16] R. A. Diamante and N. A. Banca, "Learning Styles and Skills in General Mathematics Using Alternative Delivery Mode in Relation to Mathematics Performance," United International Journal for Research \& Technology, vol. 2, no. 8, pp. 81-87, June 2021.

[17] R. A. Labarrete, "A Thematic Analyses of the Researches Conducted in the Alternative Learning System (ALS) across programs," European Journal of Education and Pedagogy, vol. 2, no. 3, pp. 46-49, 2021.

[18] R. P. Bayod, E. J. D. Forosuelo, D. A. Arnosa, H. C. Orion, and J. M. Cavalida, "Choosing Positivity in the Midst of Difficulties: The Case of Public Schoolteachers in Mindanao," Eubios Journal of Asian and International Bioethics, vol. 31, no. 2, February 2021.

[19] J. D. Calimlim, M. F. D. De Guzman, and R. N. Villalobos, "Alternative Learning Delivery Modalities (ALDM) of Secondary Social Studies Teachers: Addressing the New Normal Teaching Pedagogies," American Journal of Humanities and Social Sciences Research, vol. 5, no. 6, pp. 90-99, 2021.

[20] N. G. Dimaculangan, C. P. San Luis, and C. G. C. Gabitanan, "Teachers' Self-Assessment of their Online Teaching Readiness and Attitude," International Journal of Innovative Science, Engineering \& Technology, International Journal of Innovative Science, Engineering \& Technology, vol. 8, no. 3, pp. 325-332, March 2021. 